\title{
PENGGUNAAN JENIS MEDIA DAN PERLAKUAN PUPUK UNTUK PERTUMBUHAN ANGGREK DENDROBIUM
}

\section{USE OF MEDIA TYPES AND FERTILIZER TREATMENTS FOR THE GROWTH OF DENDROBIUM ORCHIDS}

\author{
Ida Ayu Meva Lianawati ${ }^{1}$, Ni Putu Adriani Astiti ${ }^{2}$, Ni Luh Suriani ${ }^{3}$ \\ Prodi Biologi. F MIPA,Universitas Udayana, Bukit Jimbaran - Bali \\ koresponden email :meva95liana@gmail.com \\ 2adrianiastiti@yahoo.co.id \\ 3 niluhsuriani@yahoo.com
}

\section{ABSTRAK}

Telah dapat dilakukan penelitian tentang anggrek Dendrobium yang ditanami dalam media arang kayu dan serabut kelapa serta diperlukan dengan pupuk Gandasil B media arang kayu dan serabut kelapa serta diperlakukan dengan pupuk Gandasil B dan pupuk Multitonik. Penelitian ini bertujuan untuk mengetahui pengaruh media dan pupuk terhadap pertumbuhan anggrek Dendrobium. Penelitian ini dilakukan pada bulan Mei sampai dengan Juli 2019 di Laboratorium Fisiologi Tumbuhan Prodi Studi Biologi, Fakultas Matematika dan Ilmu Pengetahuan Alam Universitas Udayana. Data yang digunakan berupa data kualitatif dan kuantitatif yang mengkombinasikan pupuk Gandasil B dan pupuk Multitonik pada media serabut kelapa dan arang kayu. Pupuk Gandasil B dengan kosentrasi $\mathrm{G}_{0}\left(0 \mathrm{~g} \mathrm{~L}^{-1}\right), \mathrm{G}_{2}\left(20 \mathrm{~g} \mathrm{~L}^{-}\right.$ $\left.{ }^{1}\right), \mathrm{G}_{3}\left(30 \mathrm{~g} \mathrm{~L}^{-1}\right), \mathrm{G}_{4}\left(40 \mathrm{~g} \mathrm{~L}^{-1}\right), \mathrm{G}_{5}\left(50 \mathrm{~g} \mathrm{~L}^{-1}\right)$. Pupuk Multitonik $\mathrm{M}_{0}\left(0 \mathrm{~g} \mathrm{~L}^{-1}\right), \mathrm{M}_{1}\left(1,1 \mathrm{~g} \mathrm{~L}^{-1}\right), \mathrm{M}_{2}$ $\left(1,2 \mathrm{~g} \mathrm{~L}^{-1}\right), \mathrm{M}_{3}\left(1,3 \mathrm{~g} \mathrm{~L}^{-1}\right), \mathrm{M}_{4}\left(1,4 \mathrm{~g} \mathrm{~L}^{-1}\right), \mathrm{M}_{5}\left(1,5 \mathrm{~g} \mathrm{~L}^{-1}\right)$. Masing - masing konsentrasi pupuk dilakukan pengulangan sebanyak 6 kali. Hasil penelitian menunjukkan pertumbuhan anggrek terbaik terdapat pada penggunaan pupuk Multitonik dan pertumbuhan jumlah daun dan jumlah akar terbanyak ditemukan pada penggunaan media serabut kelapa.

\section{Kata kunci: Arang kayu, serabut kelapa multitonik, gandasil B}

\section{ABSTRACT}

Reseach on dendrobium orchids was planted in the media of wood charcoal and coconut fibers and it is needed with Gandasil B fertilizer wood charcoal and coconut fiber media and is needed with Gandasil B and Multitonik fertilizer. This study aims to determine the effect of media and fertilizer on orchid growth and to determine pests and diseases in Dendrobium orchid plants. This reseach was conducted in May until July 2019 in the Plant Physiology Laboratory Biology Department, Faculty of Mathemathic and Natural Sciences, Udayana University. Qualitative and quantitative data are used that combine the Gandasil B fertilizer and fibers and wood charcoal media Fertilizer Gandasil B fertilizer with concetration $\mathrm{G}_{0}\left(0 \mathrm{~g} \mathrm{~L}^{-1}\right), \mathrm{G}_{2}\left(20 \mathrm{~g} \mathrm{~L}^{-}\right.$ $\left.{ }^{1}\right), \mathrm{G}_{3}\left(30 \mathrm{~g} \mathrm{~L}^{-1}\right), \mathrm{G}_{4}\left(40 \mathrm{~g} \mathrm{~L}^{-1}\right), \mathrm{G}_{5}\left(50 \mathrm{~g} \mathrm{~L}^{-1}\right)$. Fertilizer Multitonik $\mathrm{M}_{0}\left(0 \mathrm{~g} \mathrm{~L}^{-1}\right), \mathrm{M}_{1}\left(1,1 \mathrm{~g} \mathrm{~L}^{-1}\right), \mathrm{M}_{2}$ $\left(1,2 \mathrm{~g} \mathrm{~L}^{-1}\right), \mathrm{M}_{3}\left(1,3 \mathrm{~g} \mathrm{~L}^{-1}\right), \mathrm{M}_{4}\left(1,4 \mathrm{~g} \mathrm{~L}^{-1}\right), \mathrm{M}_{5}\left(1,5 \mathrm{~g} \mathrm{~L}^{-1}\right)$. Each fertilizer concentration was repeated 6 times. The results showed the best orchid growth was found in the use of Multitonik fertilizer and the best orchid growth was found in the use of Multitonik number of leavers and root growth were found in the use of coconut fibers media.

Keywords: wood charcoal, multitonik coconut fibers, gandasil B 
PENDAHULUAN

Anggrek Dendrobium adalah salah satu tanaman hias yang banyak dibudidayakan serta memiliki nilai ekonomis yang tinggi. Enam puluh delapan persen produksi anggrek Dendrobium dalam negeri dimanfaatkan sebagai tanaman hias (Anggarwulan, 2013). Produksi anggrek Dendrobium setiap tahunnya sebesar 11 $20 \%$, pertumbuhan tanaman anggrek dan pembungaan dipengaruhi oleh faktor genetik dan faktor fisiologis. Faktor genetik yaitu faktor bawaan dari masing- masing tanaman yang juga dapat mempengaruhi faktor fisiologis tanaman. (Aminuddin, 2017).

Peningkatan produksi menjadi salah satu perhatian utama dalam bidang pertanian. Keseimbangan antara produksi tingkat pertumbuhan anggrek harus tetap terjaga untuk kestabilan pertumbuhan anggrek Dendrobium. Faktor lingkungan sangat berperan dalam proses pertumbuhan tanaman yang meliputi komponen kelembaban, suhu, dan intensitas cahaya (Steenis, 2016). Pemupukan yang tepat adalah suatu usaha untuk dapat mengoptimalkan pertumbuhan vegetatif dan generatif tanaman (Hidayat, 2014). Beberapa kriteria media tanaman yang baik yaitu tidak mudah lapuk dan hancur, tidak menjadi adanya penyakit tanaman, dan mampu mengikat air dan unsur hara, (Purnama, 2013). (Budiarta, 2014). Media arang kayu berasal dari kayu yang sudah dibakar yang digunakan untuk media tanam untuk tanaman anggrek. Kelebihan media arang kayu tidak mudah lapuk dan tidak mengikat banyak air sehingga cendawan tidak mudah tumbuh (Bron, 2012).

Pupuk Gandasil B memiliki kandungan unsur hara N (20\%), P (15\%), $\mathrm{K}(15 \%)$, serta tambahan unsur mikro $\mathrm{Mg}$, $\mathrm{Mn}, \mathrm{B}, \mathrm{Cu}, \mathrm{Co}$, dan $\mathrm{Zn}$. B, Ca, Co, Cu, Fe, Mg, Mn, Mo, S. Pupuk Gandasil B dapat mempengaruhi merangsang keluarnya bunga, pembentukan buah pada tanaman mempertahankan kesehatan tanaman dan mampu menambah daya tahan terhadap serangan penyakit (Djanggola et al., 2016).

Sherin et al. (2012) berpendapat bahwa penggunaan serabut kelapa memiliki kelebihan seperti kandungan nutrisi yang lengkap yang dimanfaatkan oleh tanaman anggrek. Serabut kelapa juga dapat mempertahankan kelembaban pada akar tanaman anggrek dan tidak menyebabkan akar membusuk (Efendi, 2013). Varibel pertumbuhan yang diamati adalah pertumbuhan anggrek Dendrobium terhadap pemberian pupuk Gandasil B dan pupuk Multitonik dan yang melihat hama dan penyakit pada tanaman anggrek Dendrobium

\section{BAHAN DAN METODE}

Penelitian ini dilakukan dari Mei 2019 sampai dengan Juli 2019 di Kampus Universitas Udayana Bukit Jimbaran, Penanaman dan proses pemberian pupuk Laboratorium Fisiologi tumbuhan Fakultas Matematika dan Ilmu Pengetahuan Alam Universitas Udayana, selama tiga bulan. Sampel tumbuhan yang digunakan dalam penelitian adalah anggrek Dendrobium umur 6 bulan dalam botol kultur jaringan yang diperoleh dari Sanjiwani Orchid Denpasar.

\section{Percobaan pembibitan anggrek}

Pembibitan anggrek dilakukan pada media arang kayu dan serabut kelapa. Media dipilih yang berkualitas bagus kemudian dicuci bersih menggunakan air mengalir, serta direndam dengan air selamab2 - 4 hari. Media serabut kelapa yang akan digunakan direbus terlebih dahulu selama 5 menit. Media serabut kelapa ditiriskan kemudian dijemur sampai kering. Pupuk Gandasil B dicampur air dengan konsetrasi $\mathrm{G}_{0}\left(0 \mathrm{~g} \mathrm{~L}^{-1}\right)$, $\mathrm{G}_{1}\left(1,0 \mathrm{~g} \mathrm{~L}^{-1}\right), \mathrm{G}_{2}\left(2,0 \mathrm{~g} \mathrm{~L}^{-1}\right), \mathrm{G}_{3}\left(3,0 \mathrm{~g} \mathrm{~L}^{-}\right.$ $\left.{ }^{1}\right), \mathrm{G}_{4}\left(4,0 \mathrm{~g} \mathrm{~L}^{-1}\right)$, dan $\mathrm{G}_{5}\left(5,0 \mathrm{~g} \mathrm{~L}^{-1}\right)$. Pupuk 
Program Studi Biologi FMIPA UNUD

multitonik dicampur air dengan konsetrasi $\mathrm{M}_{0}\left(0 \mathrm{~g} \mathrm{~L}^{-1}\right), \mathrm{M}_{1}\left(1,1 \mathrm{~g} \mathrm{~L}^{-1}\right), \mathrm{M}_{2}\left(1,2 \mathrm{~g} \mathrm{~L}^{-1}\right)$, $\mathrm{M}_{3}\left(1,3 \mathrm{~g} \mathrm{~L}^{-1}\right), \mathrm{M}_{4}\left(1,4 \mathrm{~g} \mathrm{~L}^{-1}\right)$, dan $\mathrm{M}_{5}(1,5 \mathrm{~g}$ $\left.\mathrm{L}^{-1}\right)$. Anggrek Dendrobium yang sudah di keluarkan dari botol kultur jaringan dicuci bersih kemudian dibungkus dengan media serabut kelapa kemudian diikat dengan tali rapia dan semua anggrek yang sudah ditanam di tempatkan pot, di dalam green house. Kedua pupuk yang dikombinasikan pada media serabut kelapa dan arang kayu dilakukan pengulangan sebanyak 6 kali. Pengamatan hama penyakit dilakukan secara langsung pada tanaman anggrek Dendrobium bagian yang menunjukkan gejala hama penyakit diambil fotonya dan serangga yang ada di tanaman anggrek Dendrobium.

\section{HASIL DAN PEMBAHASAN}

Tanaman anggrek Dendrobium yang digunakan pada penelitian ini diaklimatisasi selama satu minggu pada suhu ruang di Laboratorium Fisiologi Tumbuhan (Tabel 1)

Hari ke- 1 s/d 7 tanaman anggrek masih terlihat subur pada kedua media. Pada minggu ke-7 daun masih terlihat segar dan
Maret 2021

tumbuhan anggrek masih terlihat subur. Hal ini dikarenakan suhu lingkungan $27^{\circ} \mathrm{C}$ di Laboratorium Fisiologi Tumbuhan sesuai dengan suhu optimal yang dibutuhkan untuk pertumbuhan anggrek. Hasil pengamatan aklimatisasi anggrek hari ke-3 s/d 7 dapat dilihat pada (Gambar 4). Daun masih terlihat hijau tanaman anggrek masih terlihat subur faktor kelembaban, cahaya, suhu sangat mempengaruhi aklimatisasi anggrek. semua tanaman anggrek tidak ada yang mengalami kematian pada saat aklimatisasi anggrek. Tidak ada hama penyakit tanaman.

Anggrek diaklimatisasi dengan menggunakan paranet sebagai melindungi agar tidak terpapar sinar matahari secara langsung. Aklimatisasi anggrek membutuhkan intensitas cahaya sebesar 40 50\% (Sukma dan Setiawati, 2011).

Faktor luar dapat mempengaruhi faktor utama yang mendukung menentukan keberhasilan aklimatisasi anggrek yang dapat menunjukkan tumbuh hidup proses aklimatisasi anggrek jumlah daun, jumlah akar dan tumbuh yang mennghasilkan pertumbuhan yang baik (Narendra, 2012).

Tabel 1. Pertumbuhan Anggrek Dendrobium Hasil Aklimatisasi.

\begin{tabular}{|c|c|c|c|}
\hline \multirow[t]{2}{*}{ Minggu ke- } & \multicolumn{2}{|c|}{ Jumlah } & \multirow[t]{2}{*}{ Keterangan } \\
\hline & Hidup & Mati & \\
\hline $\mathrm{I}$ & 45 & 0 & $\begin{array}{l}\text { Tanaman anggrek masih terlihat segar, } \\
\text { penyiraman intensif pagi }\end{array}$ \\
\hline II & 40 & 0 & $\begin{array}{l}\text { Daun anggrek masih terlihat segar semua } \\
\text { tanaman subur }\end{array}$ \\
\hline III & 40 & 0 & $\begin{array}{l}\text { Daun masih hijau semua tanaman subur dan tidak } \\
\text { ada hama penyakit tanaman }\end{array}$ \\
\hline IV & 40 & 0 & $\begin{array}{l}\text { Daun masih hijau dan tidak ada hama penyakit } \\
\text { tanaman }\end{array}$ \\
\hline V & 40 & 0 & $\begin{array}{l}\text { Daun anggrek masih terlihat segar dan tidak ada } \\
\text { hama penyakit }\end{array}$ \\
\hline VI & 40 & 0 & $\begin{array}{l}\text { Daun anggrek masih subur dan tidak ada yang } \\
\text { mati. }\end{array}$ \\
\hline VII & 40 & 0 & $\begin{array}{l}\text { Daun anggrek masih subur dan tidak ada yang } \\
\text { mati, dan daun masih terlihat hijau }\end{array}$ \\
\hline
\end{tabular}



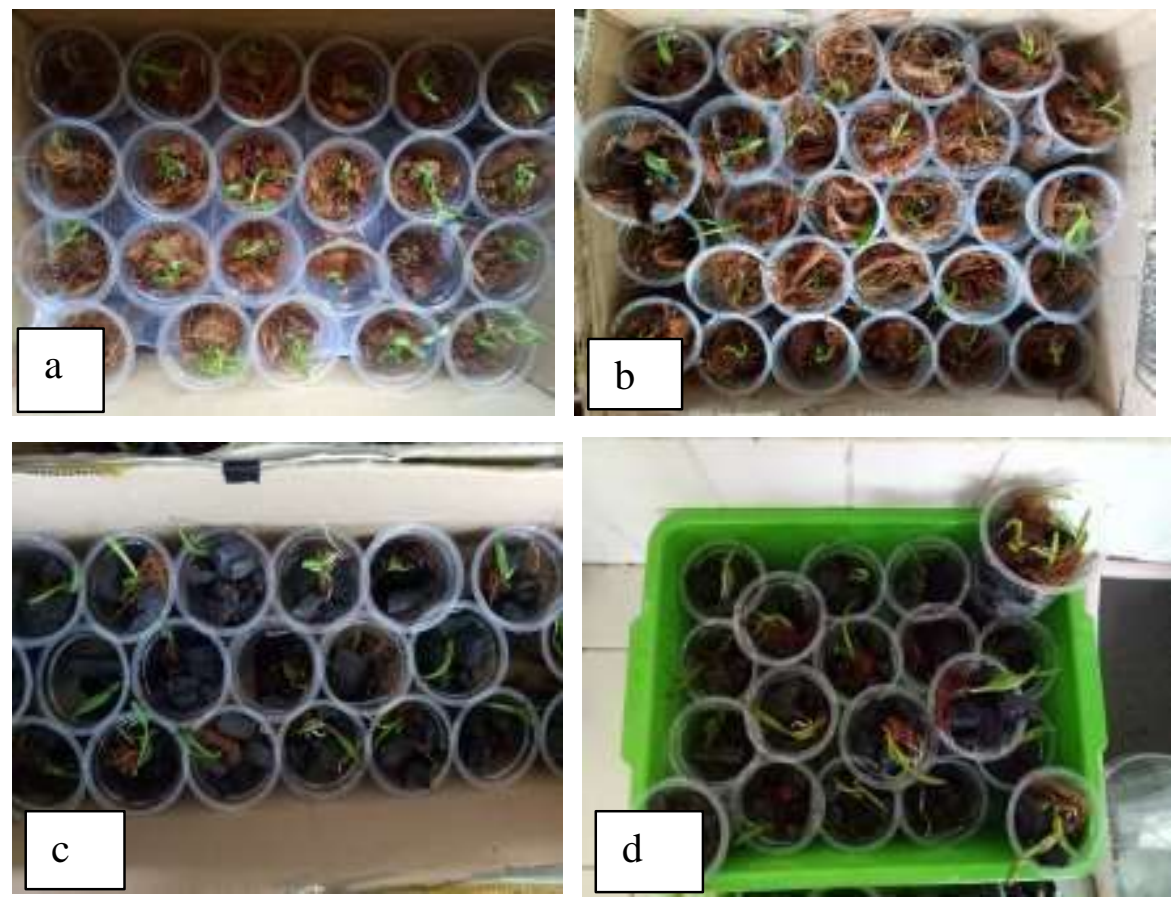

Gambar 1. Aklimatisasi anggrek hari ke-7 pada media serabut kelapa dengan pupuk b multitonik (a) dan pupuk gandasil B (b) dan media arang kayu dengan pupuk multitonik (c) dan gandasil B (d).

Tebel 2. Laporan hasil pengamatan anggrek

\begin{tabular}{clcc}
\hline No & \multicolumn{1}{c}{ Perlakuan } & Hidup & Mati \\
\hline 1 & Gandasil B serabut kelapa & 19 & 17 \\
2 & Gandasil B arang kayu & 20 & 16 \\
3 & Multitonik serabut kelapa & 23 & 13 \\
4 & Multitonik arang kayu & 21 & 15 \\
5. & Kontrol & 24 & 12 \\
\hline & & 21,4 & 14,6 \\
\hline
\end{tabular}

Pengaruh kematian anggrek dengan kosentrasi tinggi dan daya serap disebabkan karena adanya kurangnya media yang digunakan dapat penyerapan unsur hara pada tanaman mempengaruhi pertumbuhan hidup dan mati anggrek dan kematian anggrek juga nya anggrek. Pertumbuhan yang bagus yaitu berpengaruh pada kosentrasi pupuk yang pada media serabut kelapa, sedangkan pada berbeda. Menurut Harlina (2003) respon media arang kayu ditunjukkan pertumbuhan pertumbuhan anggrek yang hidup hidup terendah (Supari, berpengaruh pada zat pengantur tumbuh 2013). 
Salisbury dan Ross (2011) mengatakan bahwa cahaya matahari yang memberikan pada tanaman anggrek dalam jumlah maksimal dapat memicu terbukanya stomata, sehingga menyerapan unsur hara pada tanaman anggrek. unsur terpenuhi.

Munculnya daun merupakan salah satu tanda bahwa tanaman anggrek pada proses penanaman yang dilakukan mampu tumbuh dan berkembang. Berdasarkan hasil pengamatan jumlah daun, daun anggrek Dendrobium mulai muncul pada minggu ke-7. Hasil penelitian ditunjukkan bahwa memberikan pupuk Multitonik dapat berpengaruh terhadap pertumbuhan daun.

Menurut penelitian Widiastuti (2005) yang menyatakan bahwa banyaknya pemberian kosentrasi pupuk yang tinggi dapat menyebabkan jumlah daun anggrek yang sedikit, karena kosentrasi pupuk yang terlalu tinggi.

Rata - rata jumlah daun yang paling terbanyak diperoleh pada perlakuan pupuk Multitonik media serabut kelapa jumlah daun yaitu 8 dan terendah pada kontrol yaitu 3 daun menghasilkan jumlah daun tidak banyak berkisar 3 daun dan tidak berbeda dengan perlakuan pupuk Multitonik $\mathrm{M}_{2}(1,2$ $\mathrm{g} \mathrm{L}^{-1}$ ) media arang kayu yang menghasilkan jumlah daun 3 daun. Sebaliknya pada perlakuan pupuk Multitonik $\mathrm{M}_{3}\left(1,3 \mathrm{~g} \mathrm{~L}^{-1}\right)$ tertinggi, dihasilkan jumlah daun 8 pada media serabut kelapa. Hal ini menunjukkan bahwa media serabut kelapa dapat menyerap air lebih banyak.

Kandungan Unsur $\mathrm{N}$ dalam jaringan tumbuhan berhubungan dengan pertumbuhan jumlah daun yang selanjutnya diikuti oleh proses pertumbuhan jumlah daun. Unsur pengatur tumbuh yang dibutuhkan tanaman anggrek dalam pertumbuhan daun yaitu asam amino dan kalium yang dimanfaatkan dalam fase vegetatif (Novizan, 2001).

Menurut Sandra (2001), anggrek Dendrobium dari umur 0 sampai 7 minggu aklimatisasi, dan masa setelah tanam (MST) tidak banyak mengalami pertumbuhan jumlah daun. Pada penelitian ini, jumlah daun yang paling banyak ditemukan pada media serabut kelapa.

Hasil penelitian Wardani, (2012) pemberian pupuk Gandasil B menunjukkan pertumbuhan jumlah daun yang sama setelah penanaman selama 3 bulan sedangkan perlakuan pupuk Multitonik kosentrasi $\mathrm{M}_{1}\left(11 \mathrm{~g} \mathrm{~L}^{-1}\right)$ media arang kayu menunjukkan hasil jumlah daun 3 daun. Hal ini menunjukkan bahwa pemberian pupuk multitonik harus mempertimbangkan unsur hara yang terkandung pada pupuk Multitonik untuk pertumbuhan jumlah daun.

\section{Jumlah akar}

Oleh karena pada media arang kayu pertumbuhan anggrek yang paling rendah, semua tanaman anggrek Dendrobium pada media arang kayu mengalami pertumbuhan jumlah akar yang lebih sedikit (Limarni, et. al 2008). Perlakuan pupuk Gandasil B dengan kosentrasi $\mathrm{G}_{3}\left(30 \mathrm{~g} \mathrm{~L}^{-1}\right)$ media arang kayu kekurangan unsur hara $\mathrm{Zn}$ yang menghambat pertumbuhan akar pada tanaman anggrek. karena kurangnya penyerapan unsur hara Zn (Meliana, 2011).

Adanya proses pertumbuhan, perpanjangan akar menandakan terjadi pemanjangan akar pada tanaman anggrek. Menurut Tari (2011), unsur hara Zn disintesis pada ujung akar kemudian diangkut melalui xylem ke organ tumbuhan mendorong pembelahan sel. Pertumbuhan 
akar pada meristem akar untuk pengembangan akar akan memanjang sedangkan pada lapisan terluar tumbuh menghasilkan sistem perakaran. Pada batang akar literal.

bagian akar anggrek tumbuh pucuk literal,

Tabel 3. Jumlah daun pada perlakuan dengan pupuk Gandasil B dan pupuk Multitonik pada media arang kayu dan serabut kelapa pada umur 7 MST

\begin{tabular}{lcc}
\hline Perlakuan & \multicolumn{2}{c}{ Media } \\
\hline & $\begin{array}{c}\text { Arang } \\
\text { kayu }\end{array}$ & Serabut kelapa \\
\hline Gandasil B & & \\
Kontrol & 3,67 & 3,00 \\
G1 & 4,00 & 4,00 \\
G2 & 4,00 & 4,00 \\
G3 & 4,00 & 4,00 \\
G4 & 4,00 & 4,00 \\
G5 & 4,00 & 4,00 \\
Multitonik & & \\
Kontrol & 3,67 & 3,67 \\
M1 & 3,67 & 3,67 \\
M2 & 3,67 & 7,50 \\
M3 & 3,67 & 8,17 \\
M4 & 3,67 & 8,33 \\
M5 & 4,00 & 8,00 \\
\hline
\end{tabular}

Keterangan

Kontrol

G1 = Perlakuan pupukGandasil $\mathrm{B} \mathrm{G}_{1}\left(10 \mathrm{~g} \mathrm{~L}^{-1}\right) \quad \mathrm{M} 1=$ Perlakuan pupuk Multitonik $\mathrm{M}_{1}\left(1,1 \mathrm{~g} \mathrm{~L}^{-1}\right)$

$\mathrm{G} 2=$ Perlakuan pupuk Gandasil $\mathrm{B} \mathrm{G}_{2}\left(20 \mathrm{~g} \mathrm{~L}^{-1}\right) \quad \mathrm{M} 2=$ Perlakuan pupuk Multitonik $\mathrm{M}_{2}\left(1,2 \mathrm{~g} \mathrm{~L}^{-1}\right)$

$\mathrm{G} 3=$ Perlakuan pupuk Gandasil B $\mathrm{G}_{3}\left(30 \mathrm{~g} \mathrm{~L}^{-1}\right) \quad \mathrm{M} 3=$ Perlakuan pupuk Multitonik $\mathrm{M}_{3}\left(1,3 \mathrm{~g} \mathrm{~L}^{-1}\right)$

$\mathrm{G} 4=$ Perlakuan pupuk Gandasil $\mathrm{B} \mathrm{G}_{4}\left(40 \mathrm{~g} \mathrm{~L}^{-1} \quad \mathrm{M} 4=\right.$ Perlakuan pupuk Multitonik $\mathrm{M}_{4}\left(1,4 \mathrm{~g} \mathrm{~L}^{-1}\right)$

$\mathrm{G} 5=$ Perlakuan pupuk Gandasil $\mathrm{B} \mathrm{G}_{5}\left(50 \mathrm{~g} \mathrm{~L}^{-1}\right) \quad \mathrm{M} 5=$ Perlakuan pupuk Multitonik $\mathrm{M}_{5}\left(1,5 \mathrm{~g} \mathrm{~L}^{-1}\right)$
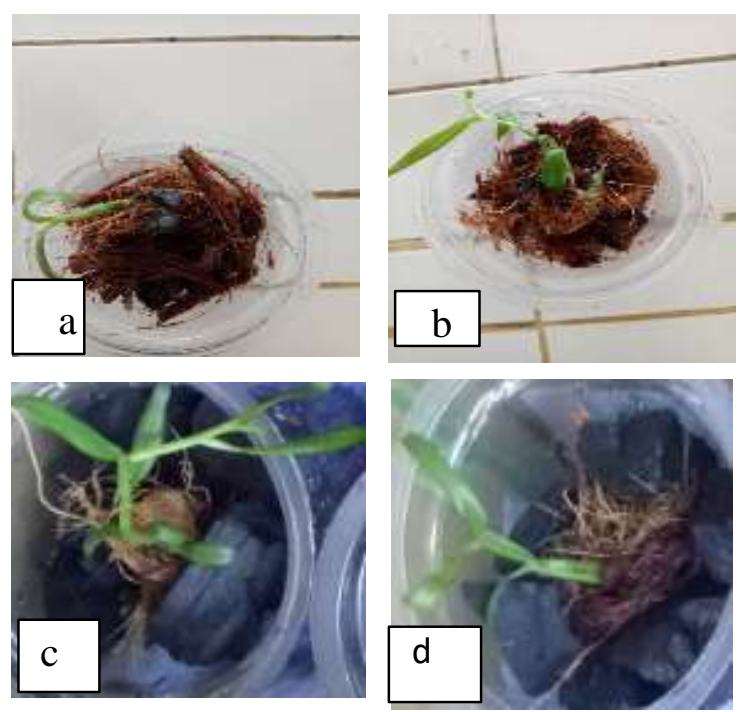

Gambar 2. Rata - rata jumlah daun pada media serabut kelapa dengan pupuk multitonik (a), pupuk gandasil B (b), media arang kayu dengan pupuk multitonik (c) dan gandasil (d). 
Tabel 4. Jumlah akar pada perlakuan dengan pupuk Gandasil B dan pupuk Multitonik pada media arang kayu dan serabut kelapa pada umur 7 MST.

\begin{tabular}{lcc}
\hline Perlakuan & \multicolumn{2}{c}{ Media } \\
\cline { 2 - 3 } \multicolumn{1}{c}{ Bandasil } & Arang kayu & Serabut kelapa \\
\hline Kontrol & 3,00 & 7,80 \\
G1 & 4,00 & 8,70 \\
G2 & 4,00 & 8,28 \\
G3 & 4,00 & 8,73 \\
G4 & 4,00 & 8,73 \\
G5 & 4,00 & 8,25 \\
Multitonik & & \\
Kontrol & 3,67 & 7,80 \\
M1 & 3,67 & 8,70 \\
M2 & 3,67 & 8,19 \\
M3 & 3,67 & 8,36 \\
M4 & 3,67 & 8,75 \\
M5 & 4,00 & 8,25 \\
\hline
\end{tabular}

Keterangan

Kontrol

$\mathrm{G} 1=$ Perlakuan pupukGandasil $\mathrm{B} \mathrm{G}_{1}\left(10 \mathrm{~g} \mathrm{~L}^{-1}\right)$

$\mathrm{G} 2=$ Perlakuan pupuk Gandasil B G $2\left(20 \mathrm{~g} \mathrm{~L}^{-1}\right)$

\section{Kontrol}

$\mathrm{M} 1=$ Perlakuan pupuk Multitonik $\mathrm{M}_{1}\left(1,1 \mathrm{~g} \mathrm{~L}^{-1}\right)$

M2 = Perlakuan pupuk Multitonik $\mathrm{M}_{2}\left(1,2 \mathrm{~g} \mathrm{~L}^{-1}\right)$

M3 = Perlakuan pupuk Multitonik $\mathrm{M}_{3}\left(1,3 \mathrm{~g} \mathrm{~L}^{-1}\right)$

M4 = Perlakuan pupuk Multitonik $\mathrm{M}_{4}\left(1,4 \mathrm{~g} \mathrm{~L}^{-1}\right)$

$\mathrm{G} 4=$ Perlakuan pupuk Gandasil $\mathrm{B} \mathrm{G}_{4}\left(40 \mathrm{~g} \mathrm{~L}^{-1}\right.$

$\mathrm{G} 5=$ Perlakuan pupuk Gandasil B $\mathrm{G}_{5}\left(50 \mathrm{~g} \mathrm{~L}^{-1}\right)$

M5 = Perlakuan pupuk Multitonik M5 $\left(1,5 \mathrm{~g} \mathrm{~L}^{-1}\right)$

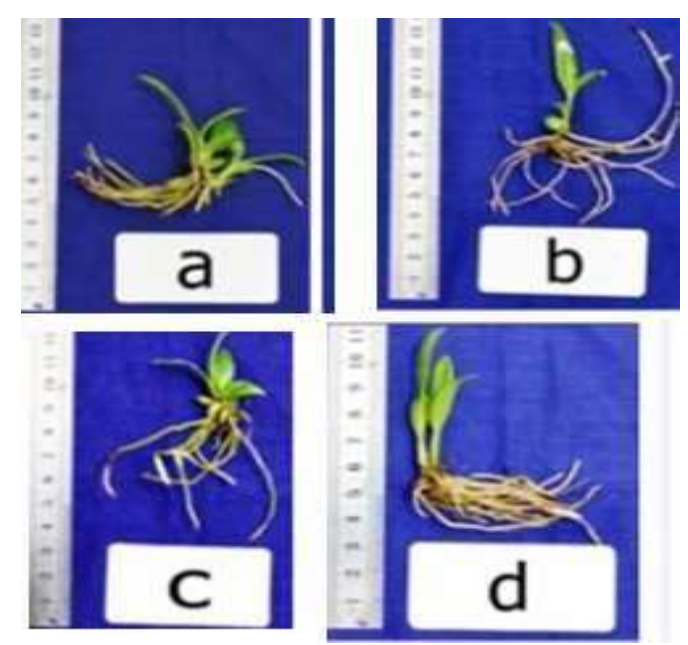

Gambar 3. Rata - rata jumlah akar pada media serabut kelapa dengan pupuk multitonik (a), pupuk gandasil B (b), media arang kayu dengan pupuk multitonik (c), gandasil B (d). 
Apabila dalam perbandingan perlakuan konsentarsi pupuk Gandasil B dan pupuk Multitonik akan memperlihatkan pertumbuhan akar dimana pupuk yang baik digunakan untuk pertumbuhan akar. Menurut penelitian Sarief (2016) pemberian perlakuan pupuk gandasil B konsentrasi $\mathrm{G}_{4}\left(40 \mathrm{~g} \mathrm{~L}^{-1}\right)$ media serabut kelapa merupakan kosentrasi yang optimal menghasilkan perkembangan akar terbaik. Hal ini menunjukkan bahwa unsur hara $\mathrm{Zn}$ mampu menginduksi pertumbuhan akar.

\section{Hama dan Penyakit}

Hama dan penyakit tanaman merupakan dua hal dan dapat menyerang tanaman. Hama dan penyakit belum ditemukan di tanaman anggrek Dendrobium sp. Penyebab umum dari serangan hama penyakit adalah karena lingkungan sekitar tanaman anggrek (Sarwono, 2012).

Selama penelitian rata - rata kondisi lingkungan selama penelitian selama 3

\section{DAFTAR PUSTAKA}

Aminuddin, A. 2017.Tanaman Anggrek Dendrobium. Jakarta: PT Gramedia Pustaka Utama.

Amir, F. dan C. Saleh. 2014. Respon pertumbuhan bibit anggrek Dendrobium sp pada saat aklimatisasi terhadap beragam frekuensi pemberian pupuk daun bunga anggrek Dendrobium Jurnal Fisiologi Tumbuhan Mulawarman 11(2):84-88.

Ariani, N. 2015. Budidaya Anggrek Dendrobium. Jurnal Chem. Tech. 1(1): 18-22.

Aziz, S. 2010. Uji Antibakteri Ekstrak bulan $28-29 \mathrm{C}^{0}$ menunjukkan kondisi yang cuaca cerah suhu selama penelitian kisaran optimal diperlukan 27- 29 $\mathrm{C}^{\circ}$ dan kelembaban udara 65\% - $90 \%$, Sehingga tidak ditemukan hama penyakit tanaman (Suryanti, 2013).

\section{Kesimpulan}

Pupuk yang baik digunakan untuk memacu pertumbuhan anggrek Dendrobium adalah pupuk Multitonik untuk pertumbuhan jumlah daun dengan menggunakan media serabut kelapa.

\section{Saran}

Perlu dilakukan penelitian lanjutan menggunakan kosentrasi pupuk dengan kisaran yang lebih tinggi dan menggunakan campuran media serabut kelapa dan moss.

\section{UCAPAN TERIMA KASIH}

Ibu Dr. Ir. Made Ria Defiani MSc, (Hons), Primawan Wicaksono, Ni Wayan Sudatri S.Si.MSi yang telah memberikan dan saran membantu dalam penelitian.

Etanol Daun dan Umbi Bakung Putih penyebab jerawat. Skripsi

Hidayatullah. Jakarta. 182.

Bron, S. 2012.Estimating Biomass and Biomass Change of Tropical Forest. Forestry Paper (134).

Budiarta, N., Fitmawati, N. Sofiyanti. 2014. Merawat Tanaman Anggrek Dendrobium.Berdasarkan Penanda Morfologi di Kabupaten Malang Singingi. JOM FMIPA. 1(2):1-8.

Chid, R. 2002. Anggrek Longman Group. Second ed London 12:564-582.

Djajadisastra, J. 2009. Formulasi Gel Topikal dari Ekstrak Nerii Folium dalam Sediaan Anti Jerawat. Jurnal Farmasi Indonesia 4(4):210-216. 
Djanggola, T. N., Yusriadi, M. R. Tandah. 2016. Pengaruh Pemberian Pupuk Terhadap Tanaman Anggrek. Galenia Journal of Pharmacy 3(1): 11-18.

Efendi 2013, Potensi Pengaruh Kosentrasi Pupuk Untuk Meningkatkan Hasil Tanaman Anggrek Jurnal, Litbang Pertanian 30 (5) 156 - 159.

Feeder, 2012. Bertanam Anggrek Jakarta: Penebar Swadaya.

Greenwood. 2015. Antibiotics Susceptibility (Sensitivity) Test, Antimicrobial and Chemotherapy. USA: Mc Graw Hill Company.

Hardini, J. B. .2015 Metode Pembuatan Media Anggrek Penentuan Cara Modern Menganalisis Tumbuhan. Bandung: ITB.

Hardoyo, F. 2010 Orchid of Indonesia.Perhimpunan Anggrek Indonesia Jakarta.

Harsiwi, K. A., A. M. Mahran, E. R. M. Hofny, K. A. Mohammed, A. M. Darweesh, A. Aal. 2011. The Impact of Dendrobium Vulgaris on the Quality of Life and Psychologic Status in Patients from Upper Eqypt. International Journal Dermatology 48(3):280-285.

Hidayat, Y. dan Sutarma. 2014. Teknik Pembuatan Kultur Media Anggrek Bogor: Balai Penelitian Veteriner. Jakarta 131 (9) :380 - 381.

Junita, 2002. Pengaruh Frekuensi Penyiraman dan Takaran Pupuk Kandang Terhadap Pertumbuhan dan Hasil Patchauli. Jurnal Ilmu Pertanian UGM.

Kartina, Z. Z., M. Assi, T. A. Moore. 2016. Recurrent Epidural Abcess Caused by Dendrobium. Khansas Journal of Medicine 92-95.
Kencana, IP. 2007. Cara Cepat Menghubungkan Anggrek. Gramedia Jakarta.

Khan, Z. Z., M. Assi, T. A. Moore. 2009. Recurrent Epidural Abcess Caused by Propionibacterium acnes. Khansas Journal of Medicine 92-95.

Lakmi, L., A. H. Lieberman, J. L. Kanig. 2015. Teori Pembibitan Anggrek Dendrobium II. Penerjemah: Siti Suyatni. Edisi Ketiga. Jakarta: Universitas Indonesia.

Limarni, L., N. Akhir., I. Suliansyah dan A. Riyandi. 2008. Laporan Penelitian Bibit Anggrek (Dendrobium sp) dalam Kompot Pada Beberapa Jenis Media dan Kosentrasi Vitamin B1. Jurnal Penelitian Jerami 1: 87-89.

Mardani, K. R. 2015. Perbanyakan Anggrek Dendrobium. Bandung: ITB Press.

Media tanam dan letak tanaman pada sistem Pertanian. Gramedia Jakarta

Meliala, L. A. 2011. Pengelolaan Usaha Bunga Potong Lisianthus di PT. Saung Mirwan, Megamendung, Bogor, Jawa Barat. Departemen Agronomi dan Hortikultura, Fakultas Pertanian, ITB.

Mochadi, M. 2012. Pengaruh Pemberian Larutan Air Kelapa (Cocos nucifera) dengan Penambahan Larutan Gula Terhadap Kesegaran Bunga Mawar Potong (Rosa hybrida). Skripsi. Fakultas Keguruan dan Ilmu Pendidikan, Universitas Muhammadiyah Surakarta

Monika, 2013. Pemupukan Pemberian pupuk Gandasil D terhadap pertumbuhan anggrek macam media terhadap pertumbuhan bibit anggrek Dendrobium sp Biologi Universitas Indonesia Press. 
Narendra, 2012. Diagnosis Defisiensi dan Toksisitas Hara Mineral pada tanaman Tanaman Makalah Falsafah Sain. Program Pasca Sarjana IPB. Bogor.

Novero dan Tombe. 2013. Uji Anggrek In Vitro terhadap Beberapa Jamur Patogenik Tanaman. Jurnal Buletin Tropika 14:2.

Novi, S., R. D. Pratiwi, E. Gresinta. 2015. Zat Pengatur Tumbuh. 8(1):75-78.

Novizan, 2012. Petunjuk Pemupukan yang Efektif. Penerbit Agremedia Pustaka, Jakarta $144 \mathrm{~h}$.

Nuriana, 2015. Kurtur Jaringan Anggrek Skala Rumah Tangga, PT Agro Media Pustaka, Bogor.

Purnama, S. R., E. Yuniastuti, M. P. Sri Hartati. 2010. Karakterisasi Morfologi Tanaman Anggrek Dendrobium ProsidingSeminar Nasional Pendidikan Biologi FKIP UNS 2013.

Purwantoro, S. M. 2005. Penuntun Ilmu Tumbuhan Medik. Jakarta: Universitas Indonesia Press.

Salisbury, F. B., dan C. W. Ross 2011. Fisiologi Tumbuhan III Perkembangan Tumbuhan dan Fisiologi Lingkungan. Terjemahan. D.R Lukman Sumaryono. Penerbit ITB Bandung.

Sandra, D. 2001. Membuat Anggrek Rajin Berbunga Anggrobisnis Pustaka Jakarta. 54 hlm.

Sarah, M., M. R. J. Runtuwene, H. E. I. Simbala, V. M. A. Makang. 2015. Analisis Fitokimia Tumbuhan di Kabupaten Minahasa Utara. Chemistry Progress 1:47-53.

Sarief, 2016. Kesuburan Dan Pemupukan Tanah Pertanian. Pustaka Buana.

Sarwono, 2012. Menghasilkan anggrek potong kualitas prima. Jakarta: Penebar Swadaya.
Setiadi, Y. 2015. Pemanfaatan Daun anggrek dan Kehutanan. Bogor: Bioteknologi IPB.

Sri Windari, Hot Setiado, dan Syarifuddin II 2011.Pengaruh Media Tanam dan Pupuk Daun terhadap Aklimatisasi Anggrek (Dendrobium sp). Jurnal Pertanian Kultivar Vol 5 No 12011. Diakses 18 September 2018.

Sriwati, M. 2016. Penuntun Fitokimia dalam Farmasi. Bandung: Penerbit ITB.

Steenis, V. C. G. G. J. 2016. Anggrek Dendrobium. Jakarta: PT Pradnya Paramita.

Suciyanti, H., E. Sulistyowati, Y. Fenita. 2015. Evaluasi Nutrisi Serabut Kelapa yang Difermentasi Jamur Tiram Putih (Pleurotus ostreatus) pada Masa Inkubasi yang Berbeda. Jurnal Sain Peternakan Indonesia 10(2):77-86.

Sudharmono, A. 2008. Laser Skin Resurfacing. Seminar Perspective of Laser Dermatology Surabaya.

Sugita, T., M. Miyamoto, R. Tsuboi, K. Takatori, R. Ikeda, A. Nishikawa. 2010. In Vitro of Dendrobium Isolated from Patients with vulgaris. Biol. Pharm. Bull. 33(1):125-127.

Sukma, D., dan A. Setiawati. 2011. Pengaruh Waktu Frekunsi Aplikasi Pupuk Daun Terhadap Pertumbuhan dan Pembungaan Anggrek Dendrobium Tong Chai Gold'. J. Hort. 1 (2) : 97 - 104.

Supari, D. 2013. Anggrek Dendrobium sp Anggrobisnis Pustaka Jakarta. 56 hlm.

Suradinata, Y. R., A. Nuraini., dan A. Setiadi 2012. Pengaruh Kombinasi Media Tanam dan Kosentrasi Pupuk Daun Terhadap Pertumbuhan Tanaman Anggrek Dendrobium sp. 
pada Aklimatisasi. J. Agrivigor 11 (2) :104 - 116 Bandung.

Surtinah dan E. Mutryarny. 2013. Frekuensi Pemberian Grow Quick LB Terhadap Pertumbuhan Bibit Anggrek Dendrobium Pada Stadia Komunitas Pot. Jurnal Ilmiah Pertanian 10(2):31-41.

Suryanti, 2013 Respon Produksi Tanamn Anggrek Dendrobium terhadap jenis

Sutinah, M. 2013 Meningkatkan Produksi Tanaman Dengan Pupuk Daun. Trubus.

Tari, P., B. Kumar, M. Kaur, G. Kaur, H. Kaur. 2011. Phytochemical Screening and Extraction: A Review. International Pharmaceutica Sciencia 1(1):96-106.

Widiastuti, H, N. Sukarno, L. K. Darusalam, D. H. Goenadi, S. Smith, E. Guhardja 2005. Penggunaan Spora Cendawan Mikoriza Arbuskula sebagai Inokulum untuk meningkatkan Pertumbuhan dan serapan hara bibit kelapa sawit. Jurnal Menara Perkebunan 73(1):26-34.
Tarmedi, R. I. S. 2006. Keanekaragaman Tanaman Anggrek Dendrobium Jakarta: PT Gramedia Pustaka Utama.

Vidyawati, 2016. Pemupukan Pemberian pupuk Gandasil D terhadap pertumbuhan anggrek macam media terhadap pertumbuhan bibit anggrek Dendrobium sp Biologi Universitas Indonesia Press.

Wardani, 2012, M., S. Hardjono, S. Respati. 2015. Pengantar Praktikum Fisiologi Tumbuhan Yogyakarta: UGM Press. 